\title{
Survey of hepatitis B and C infection control: procedures at manicure and pedicure facilities in São Paulo, Brazil
}

Authors

Andréia Cristine Deneluz Schunck de Oliveira

Roberto Focaccia ${ }^{1}$

${ }^{1}$ Instituto de Infectologia Emílio Ribas.
Submitted on: 08/25/2009 Approved on: 12/11/2009

Correspondence to: Andréia Cristine Deneluz Schunck de Oliveira R: Martiniano de Carvalho, 14 apto 203. Bela Vista - São Paulo CEP: 01321-000

Mobile phone: $+55-11$ 97794492

Phone: +55-11-38961233 E-mail: andreiaschunck@ hotmail.com

We declare no conflict of interest.

\begin{abstract}
Bleeding due to the habit of removing the cuticles of the finger and toes nails, without appropriate sterilization of instruments can be an important factor of contamination by hepatitis B and C viruses. The objectives of this study were to verify the use of standards on biosafety in the routine work of manicurists and/or pedicurists located in São Paulo, Brazil; know the level of information they have about ways of transmission and prevention of hepatitis B and C; evaluate the degree of risk perception for accidental exposure to infectious agents; and to estimate the prevalence of serological markers of hepatitis B and C among them. This was descriptive, cross-sectional study that included a random sample of 100 manicurists and/or pedicurists working in beauty salons. We administered a questionnaire to obtain personal information about the characteristics of the participants, collected blood for hepatitis $\mathrm{B}$ and $\mathrm{C}$ serology and assessed the working environment. Adherence to the professional standards on biosafety has been inadequate, and we noted that only $5 \%$ used disposable gloves, none washed their hands, 93\% did not previously cleaned their working material and only 7\% used disposable materials. A low level of knowledge about the routes of transmission, prevention, standards of biosafety, and risk perception of the infectious agents in their professional activity was observed. One out of ten interviewed manicurist and/or pedicurist had serological markers of hepatitis B or $\mathrm{C}$, with $8 \%$ of hepatitis $\mathrm{B}$ and $2 \%$ of hepatitis $\mathrm{C}$.
\end{abstract}

[Braz J Infect Dis 2010;14(5):502-507]@Elsevier Editora Ltda.

\section{INTRODUCTION}

Manicurists and pedicurists are professionals engaged in treatment or beautification of hands and feet. ${ }^{1}$

Beauty treatments, such as piercing, tattooing, manicures, and barbers are used by many people in São Paulo city. During these procedures, the instruments can very often be contaminated with blood from the client, and most of them, if not properly sterilized, can act as a means of parenteral transmission of hepatitis B and $\mathrm{C}$ viruses. ${ }^{2}$

While in developed countries only $5 \%$ of patients with chronic hepatitis $\mathrm{B}$ or $\mathrm{C}$ have no risk factors identified, this phenomenon occurs in about $40 \%$ to $50 \%$ of patients in underdeveloped or developing countries; it seems that the vast majority of infections occur through sharing of infected material, usually by sharing cutting or perforating tools. ${ }^{3}$

Viral hepatitis is a serious public health problem in Brazil and worldwide. The habit of removing the cuticles of fingernails and toenails is a cultural practice typical of Brazil, which may be an important way of transmission of hepatitis B and C. Manicurists and pedicurists also remove their own cuticles, becoming themselves the gateway to possible infectious agents by contact with the blood from customers, apart from the risk of infecting their customers. Thus, these professionals are at risk of both being infected and infecting their clients. ${ }^{4}$

A literature review found that the frequency hepatitis $B$ and $C$ virus infection among professionals in Brazil is not known. As for hepatitis C, the only effective measure to reduce the risk of infection is to properly follow the standards on biosafety. While for hepatitis B vaccination is the best preventive measure against infection and its serious consequences. . $^{5,6,7}$

The risk of transmission of hepatitis $B$ (HBV) and $\mathrm{C}(\mathrm{HCV})$ manicurists and pedicurists stimulated the interest in studying the actual work conditions of these professionals. 


\section{OBJECTIVES}

This research aimed to evaluate the degree of knowledge on routes of transmission, prevention and perceived risk of accidental exposure, biosafety standards, and estimate the prevalence of serological markers of hepatitis B and C in manicurists and/or pedicurists working in beauty salons in São Paulo.

\section{METHODOLOGY}

The study population was comprised by professional manicurists and/or pedicurists working in beauty salons of shopping centers and district of São Paulo, Brazil. The study was conducted in the beauty centers.

This is a descriptive, seroepidemiological, cross-sectional prospective study. The sample comprised 100 professional manicurists and/or pedicurists in beauty salons, 50 sampled in neighborhoods, and 50 in shopping centers, randomly. In São Paulo, there is no record of the total professional manicurists and/or pedicurists, because the profession is not regulated, but it is performed by anyone who has interest on it. These manicurists and/or pedicurists are found in all regions of São Paulo, Brazil, so it is an unknown universe. The sample was organized according to some criteria:

1) The neighborhoods were randomly defined: first, the districts were grouped into regions. Afterwards, two subdistricts were randomly selected from each region, making a total of ten sub-districts and, from these districts, ten neighborhoods were randomly selected.

2) The shopping centers registered at the Brazilian Association of Shopping Centers were randomly selected. A total of 27 shopping centers entered the drawing in November 2006, and were divided by geographical region of the city. Ten shopping centers were randomly selected and five professional manicurists and/or pedicurists were selected from each shopping center.

The following inclusion criteria were considered:

1) Being a professional manicurist and/or pedicurists, above 18 years old;

2) Agree to participate, in writing, after verbal explanation on the objectives and methodology of the research.

All research participants, who received a consent form, were informed about the purpose and procedures of the study. After acceptance, understanding and signing this form, the research was conducted at the beauty parlor. In case of refusal, this professional was replaced by another from the same beauty salon, or the researcher would move to the next facility, always in the same block, and always walking clockwise on the block. In the absence of one in that block, the researcher would move to the next block, and so on. The interviews were carried out from November 2006 to February 2007.
In addition to the questionnaire, the structure, the cleanness, the sterilization procedures, the general procedures and the worker's health were observed as part of the research.

\section{RESULTS}

From the starting 100 professional manicurists and/or pedicurists, $96 \%$ agreed to participate and $4 \%$ declined, being replaced by other manicurists and/or pedicurists, in order to complete the research sample.

One out of each ten interviewed manicurists and/or pedicurists had serologic markers for hepatitis B or C, and eight of these professional were hepatitis $\mathrm{B}$ carriers $(8 \%)$ and two were hepatitis C carriers (2\%).

In relation to procedures employed by these manicurists and/or pedicurists when in contact with blood from customers, 54\% reported not taking any action, and the other $46 \%$ reported making several mistakes, even cleaning their hands with towels used during the clients' sessions.

In Figure 1, we verify the awareness of diseases that the manicurists and/or pedicurists say they can transmit or acquire during their professional activity.

The study verified that $66 \%$ of professionals reported that the importance of washing their hands as an act of personal hygiene is not an important measure for preventing infections.

Among the interviewed professionals only $74 \%$ reported washing hands every time between customers' sessions. It was also observed that in none of the beauty salons researched there were sinks, dispensers for both

Figure 1: Distribution of diseases that manicure and/or pedicure the municipality of São Paulo reported that can transmit and acquire during their career, 2006-2007.

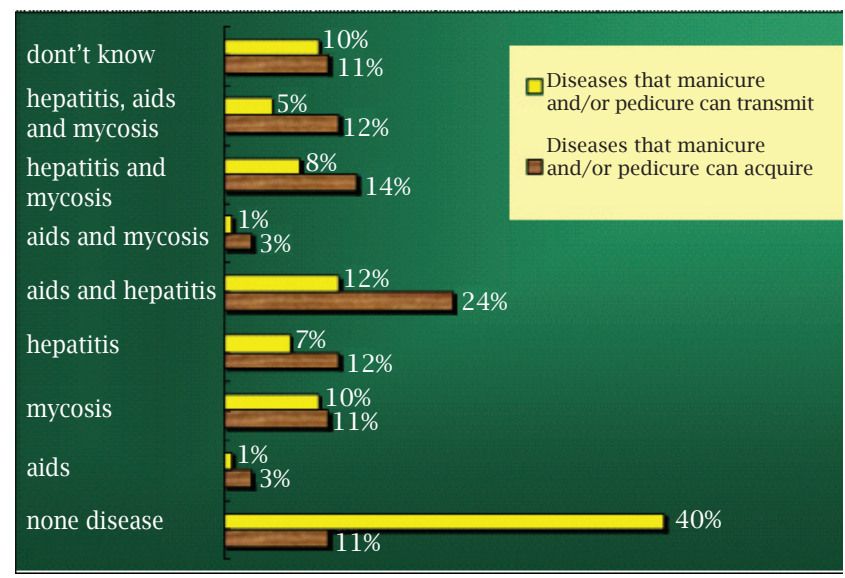


soap and tissues, in addition, none of the interviewed professionals washed their hands during procedures; those items were observed in both the beauty salons on the streets as well as in the ones in the shopping centers.

In this study, $80 \%$ of the manicurists and/or pedicurists did not use surgical gloves during the procedures, despite the fact that the majority (84\%) of these professionals said that the gloves were an instrument for their protection, and for the protection of their customers. Only $5 \%$ of the $20 \%$ that declared using gloves actually used them during the procedures.

Ninety-three percent of the manicurists and/or pedicurists reused disposable materials (sandpapers, sticks and plastic bags used as protection for sinks and washbasins).

Instrument sterilization used by these professionals at the shopping centers was the use of autoclaves (68\%), while on the beauty salons located outside the shopping centers the most used method of sterilization was the stove $(60 \%)$. Cleaning the equipment manually previous to the sterilization did not happen in $93 \%$ of the beauty salons researched, and, in the salons in which this procedure was adopted, the procedures were not appropriate and there was no use of individual protection.

As to the degree of awareness of the manicurists and/ or pedicurists, related to the proper use, time and temperature, for sterilization, it was verified that only $7.14 \%$ of the professionals who used the stove knew the proper time and temperatures and, among those that did use the autoclave, none had such knowledge (Figure 2).

Regarding the degree of knowledge and level of awareness about viral hepatitis routes of transmission and prevention, $72 \%$ did not know the transmission routes of

Figure 2: Distribution of the extent of knowledge of manicure and/or pedicure the municipality of São Paulo, for the ideal time and temperature for sterilization of instruments, 2006-2007.

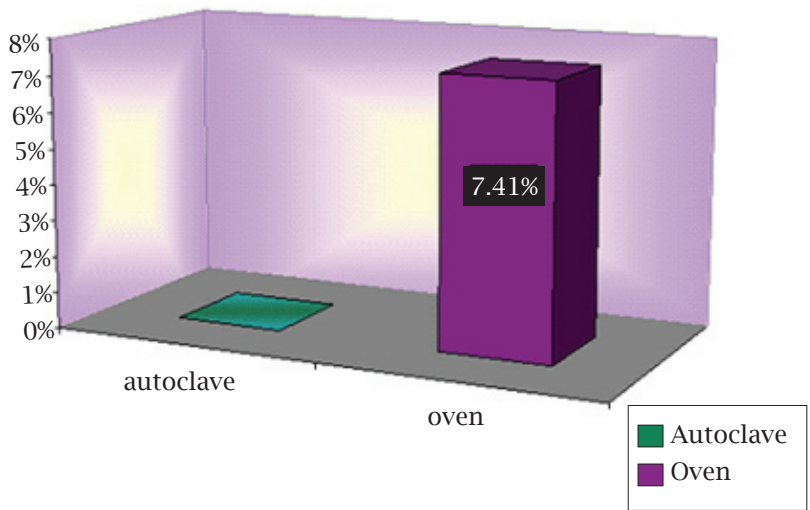

hepatitis B and $93 \%$ did not know how to prevent it. As to hepatitis C, $85 \%$ knew how the transmission occurred and $95 \%$ did not know how to prevent it; the other 3\% knew properly about it, as shown in Figure 3.

Figure 3: Distribution of the degree of knowledge of modes of transmission and prevention of hepatitis B and C of manicure and/or pedicure the municipality of São Paulo, 2006-2007.

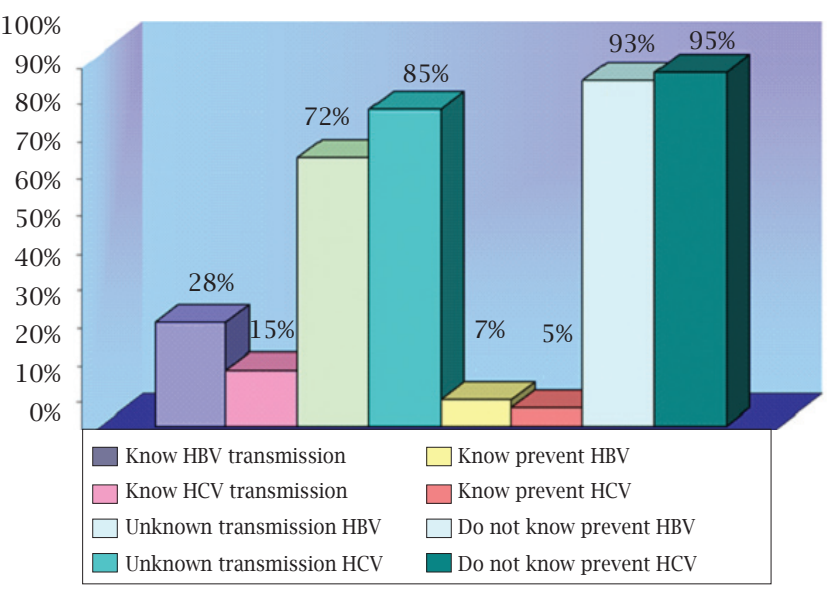

\section{DISCUSSION}

The medical literature shows the importance of the hepatitis $\mathrm{B}$ and $\mathrm{C}$ infection associated with beauty treatments like tattoos, body-piercings, manicure, and hairdressing in matters of public health..$^{8,29}$

Hepatitis B and C are infections that, in most cases, progress asymptomatically and can show clinical signs only decades after the infection; can progress into hepatic cirrhosis, liver cancer, chronic hepatic failure and autoimmune diseases. Hepatitis B and C are frequently transmitted by contaminated blood. The hepatitis B virus can stay viable outside the organism for almost a week, which allows presuming that even a minor bleeding caused during a manicure session can provide an entrance route to pathogenic organisms. ${ }^{10}$

The acceptance level, from the professional manicurists and/or pedicurists, in this research was of $96 \%$ from the initial sample, greater than in a similar research conducted in North York, Canada, in 2001, when only $60 \%$ of the professionals agreed to participate. ${ }^{8}$

This study strongly reveals the lack of knowledge by the professionals towards the disease contamination risk during their professional activities and towards procedures they should follow in order to avoid diseases; nor 
they were aware of the necessity of the hepatitis B vaccination. All of this is in agreement with the Carlomagno study ${ }^{11}$ which concluded that the majority of pedicurists and/or manicurists did not know the biological, chemical and ergonomic risks present in their profession or the ways to prevent such risks. ${ }^{12-14}$

Our study revealed that the ways these professionals tried to protect themselves after an occasional bleeding during work did not follow any protocol. After the exposure to biological material, treating the exposed area immediately is of extreme importance, it is recommended to wash the area with water and soap, using alcohol in cases of dermal or subdermal exposure. ${ }^{15}$

Around $74 \%$ of the professionals interviewed reported having the habit of washing their hands between sessions; however, it was observed during the research that none of the professionals did it. Failing to wash the hands can increase the possibility of infecting and being infected by diseases, and that usage of gloves does not exclude the need for washing the hands. Although it is the most important measure to prevent infection and it is acknowledged for many years as prevention control of infections on health services, to put it on practice turns out to be a fairly hard and complex task, finding a very strong cultural barrier among us. ${ }^{16}$

The structure required to wash the hands (sinks, soap, and paper towels dispensers) must be of easy access, near to the working areas; $;^{17,18}$ however, in none of the beauty salons researched those structures were observed.

This shows, probably, that the manicure and/or pedicure training courses are not preparing these professionals adequately, as well as the beauty salons are not prepared to perform such training or the improvement of those professionals. The conclusion is that these professionals can acquire and transmit diseases without even realizing the risk of their profession.

In this study, $80 \%$ of the manicurists and/or pedicurists did not use surgical gloves during the procedures. Only $5 \%$ of the $20 \%$ that declared using gloves really used them during the procedures. Likewise the study by Johnson et al. ${ }^{8}$ in Canada, found out that only $4.1 \%$ of the manicurists used gloves consistently during the procedures. This result indicates the lack of consciousness and control from the government and the beauty salons' owners, besides the need for regulation, and of an official protocol setting the right procedures for these professionals.

The guide "Beleza com Segurança" (Beaty with security), ${ }^{10}$ provided by the government, recommends, for manicurists and pedicurists, the use of surgical gloves, hands washing, cleaning and sterilizing the instruments; however, the book does not explains in detail how to perform these procedures. The objectives of the protection equipments are not only for the protection of these professionals, but it has a role in decreasing the risk of transmitting microorganisms.

The gloves work as a barrier, preventing hands contamination and reducing the transmission of pathogenic microorganisms from the professionals to their clients. ${ }^{15}$

Zahraoui-Mehadji et al. ${ }^{9}$ while studying hairdressers and barbers in Morocco, states that the working conditions are dangerous, because the owners of the beauty salons overlook the issues related to hygiene and the worker's safety and health, situation that appears to agree with what occurs in most countries of lower social-cultural levels. It is curious to observe that in Canada, even though it is an economically developed country, there are still situations similar to those in countries with lower cultural level, perhaps because of the high levels of immigration, like Johnson et al. ${ }^{8}$ describe in North York, which reveals the lack of information and training in the infection control towards the professionals in the beauty salons.

The instruments used by manicures and pedicure treatment require sterilization due to the risk of transmitting diseases they offer to the users, through cuts and bleedings, in cases of accidents, since in most of the sites researched, the clients did not have the habit of taking their own instruments as a way of prevention. ${ }^{19}$

The percentage of professionals who used of sterilization methods in our research was higher than that found by Johnson et al. ${ }^{8}$ in Canada, where only $1 \%$ of the professionals used the autoclave and $49 \%$ did not use any sterilization method at all. At the present study, it was observed that the majority of the professionals interviewed did not clean the instruments prior to use with clients, and the professionals that used the stove did not have the recommended external thermometer or thermostat; none of these professionals respected the proper time or temperature used for sterilization, interrupting the process by opening the stove before the end of the sterilization. A situation very much alike was found in a study conducted by Gir et al. ${ }^{20}$ in the city of Ribeirão Preto, SP, with manicurists.

The cleaning of the materials is as much an essential procedure as sterilization and must be made immediately after use of these materials, avoiding the residuals to dry on the instruments, making its removal more difficult. ${ }^{19,21}$

The most frequent failure in the beauty salons happens during the manicure and pedicure instruments' sterilization. ${ }^{10}$

Among the manicurists and pedicurists procedures, there is not the habit of disinfecting the furniture. Our research agrees with the study by Zahraoui-Mehadji, in Morocco, 2004, with barbers, where the disinfection of the working areas was not considered essential by any of the professionals interviewed. ${ }^{9}$ 
It was found out, in this research, that only $7 \%$ of the material used in the beauty salons was disposable, and that $93 \%$ of these disposable materials (sandpapers, sticks and plastic bags used as protections for sinks and washbasins), were reused. In the study by Johnson et al., ${ }^{8}$ in Canada, it was shown that from $95 \%$ to $100 \%$ of the materials were reused, even though it was not recommended by the manufacturer. The reuse of these materials is a potential way of infection. The main issue is that a cut caused by a reused instrument can transmit blood borne infections.

The level of lack of knowledge found in this study was relatively higher when compared to the one found by Focaccia et al., with the population of São Paulo, SP, in $1998 .^{22}$ In this study, the authors found an estimate of $1.42 \%$ of subjects, between two and eighty years old, infected by the hepatitis $\mathrm{C}$ virus amongst the population of São Paulo. The estimated prevalence was increasing according to the age. In the age correspondent to our study, the prevalence was always higher than $2 \%$.

Information from the media revealed that only $0.4 \%$ of the beauty salons in São Paulo have authorization from governmental agencies (health and hygiene), which indicates that $99.6 \%$ of these beauty salons are illegal. In 2007, the city of São Paulo had only five health inspectors to coordinate this activity.

It is beyond any doubt that there is a big flaw in the hepatitis control official programs when it relates to the prevention of this infection, putting at risk the health manicurists and pedicurists, their clients and the community. We can hypothesize that such actions are absent to other professionals, who deal with piercing and cutting material, as well.

The extent of the problem that viral hepatitis B and $C$ represents for public health through manicurists and/ or pedicurists suggests the need of a specific program of great impact in the preventive area.

\section{CONCLUSION}

The results allow us to conclude that:

- The level of knowledge of the manicurists and/or pedicurists, in São Paulo, is very scarce about the ways of transmission, prevention and perception of the risk of the infectious agents during their professional activities, as much as the lack of instructions to the biosafety rules.

- The prevalence of the hepatitis B viral infection among these professionals, higher than in the general population, suggests that they constitute a separate risk group, in the city of São Paulo, and are a threat to their clients and personal contacts.

\section{Recommendations}

The results and conclusions shown in this study and the epidemiologic importance of the professionals of the beauty market as spreaders of infectious diseases, allow us to offer the following recommendations.

- Elaboration and implementation of a wide educational program through the national and state program of viral hepatitis control in preventive area, focused on the beauty salons, on the transmission and prevention of hepatitis $\mathrm{B}$ and $\mathrm{C}$ for manicurists or pedicurists.

- Wide program for awareness and knowledge to all the beauty salon professionals of the country, through written media, lectures, training better professionals as health multipliers amongst their co-workers, elaboration of a flowchart for procedures in cases of accidents with biological material, amongst other measures aiming the better acknowledgement of biosafety basic cares.

- Wide public information campaign to the population talking about the use of personal material in procedures taken in beauty salons.

- Regulation of the beauty salon professionals.

- Strict control by the municipal health departments in the legalization of these professionals and salons, extensive monitoring, by health inspectors, of beauty salons.

- Guidance and supervision to the preparatory courses for professionals in the area.

- Rigorous viral hepatitis B vaccination campaign directed to these professionals.

\section{REFERENCES}

1. Ministério do Trabalho e Emprego (BR). Portaria no 397, de 9 de outubro de 2002. Aprova a Classificação Brasileira de Ocupações - $\mathrm{CBO} / 2002$, para uso em todo território nacional e autoriza a sua publicação. Diário Oficial da União, Poder Executivo, 10 out. 2002, Seção 1, p. 74.

2. Mariano A, Mele A, Tosti ME et al. Role of beauty treatment in the spread of parenterally transmitted hepatitis viruses in Italy. J Med Virol 2004; 74:216-20.

3. Focaccia R. Tratado de hepatites virais. 2a ed. São Paulo: Atheneu, 2007.2v.

4. Centers for Disease Control and Prevention (CDC). Updated U.S. Public Health Service guidelines for the management of occupational exposure to HBV, HCV, and HIV and recommendations for postexposure prophylaxis. MMWR Recomm Rep 2001; 50(RR11):1-42.

5. American Academy of Pediatrics, Committee on Infectious Diseases (US). Red Book: 2006 report of the Committee on Infectious Diseases. 27th ed. Elk Grove Village (US): The Academy, 2006.

6. Centers for Disease Control and Prevention (CDC). A comprehensive immunization strategy to eliminate transmission of hepatitis B virus infection in the United States: recommendations of the Advisory Committee on Immunization Practices (ACIP), part II: immunization of adults. MMWR Recomm Rep. 2006; 55(RR16):1-25. 
7. World Health Organization, Department of Vaccines and Biological. Introduction of hepatitis B vaccine into childhood immunization services: management guidelines, including information for health workers and parents. Geneva: WHO, 2001. Report WHO/V\&B/01.31

8. Johnson IL, Dwyer JJM, Rusen ID et al. Survey of infection control: procedures at manicure and pedicurists establishments in North York. Rev Can Santé Publique 2001; 92(2):134-7.

9. Zahraoui-Mehadji M, Baakrim MZ, Laraqui $\mathrm{S}$ et al. Risque infectieux lié au sang chez les coiffeurs-barbiers traditionnels et leurs clents au Maroc. Cahiers Santé 2004;14:211-6.

10. São Paulo (Cidade). Secretaria da Saúde. Coordenação de Vigilância em Saúde. Beleza com segurança: guia técnico para profissionais. São Paulo: COVISA, 2005.

11. Carlomagno ACC, Conceição MV, Isaías RC et al. A percepção da manicure frente aos riscos ocupacionais em sua prática de trabalho [monografia]. Ribeirão Preto: Centro Universitário Barão de Mauá, 2000.

12. Ministério da Saúde (BR). Secretaria de Políticas da Saúde. Coordenação Nacional de DST e AIDS. Manual de condutas em exposição ocupacional a material biológico. Brasília, 1999.

13. Oppermann CM, Pires LC. Manual de biossegurança para serviços de saúde. Porto Alegre: PMPA/SMS/CGVS, 2003.

14. Richtmann R. Guia prático de controle de infecção hospitalar. São Paulo: Soriak, 2005.

15. Agência Nacional de Vigilância Sanitária (BR). Curso básico de controle de infecção hospitalar: caderno C: métodos de proteção anti-infecciosa. Brasília, 2000.
16. Agência Nacional de Saúde (BR). Higienização das mãos em serviços de saúde. Brasília, 2007.

17. Rutala WA. APIC guidelines for infection control practice. Am J Infect Control 1996; 24(4):313-42.

18. Centers for Disease Control and Prevention (CDC). Guideline for hand hygiene in health-care settings: recommendations of the Healthcare Infection Control Practices Advisory Committee and the HICPAC/SHEA/APIC/ IDSA hand hygiene task force. MMWR Recomm Rep 2002; 51(RR-16)

19. Romano JC. Esterilização de instrumentais de manicure/pedicure. [citado 30 jun 2007]. Disponível em: http://www.hospvirt.org.br/enfermagem/port/ manicure.htm.

20. Gir E, Costa FPP, Silva AM. A Enfermagem frente a acidentes de trabalho com material potencialmente contaminado na era do HIV. Rev Esc Enf USP 1998 [citado 4 ago. 2008];32(3):26272. Disponível em: http://www.ee.usp.br/ reeusp/ upload/ pdf/441.pdf.

21. Associação Paulista de Estudos e Controle de Infecção Hospitalar. Limpeza, desinfecção de artigos e áreas hospitalares e antissepsia. 2a ed. rev. São Paulo: A Associação, 2004.

22. Focaccia R. Prevalência das hepatites virais A, B, C, e E: estimativa de prevalência na população geral da cidade de São Paulo, medida por marcadores séricos, em amostragem populacional estratificada com sorteio aleatório e coleta domiciliar [tese]. São Paulo: Faculdade de Medicina, Universidade de São Paulo; 1997. 